\title{
Acute Lung Injury Fibroblast Migration and Invasion of a Fibrin Matrix is Mediated by CD44
}

\author{
Kent Svee, ${ }^{\star}$ James White, ${ }^{\ddagger}$ Pierre Vaillant, ${ }^{\star}$ Jose Jessurun, ${ }^{\S}$ Urvashi Roongta, ${ }^{\star}$ Marci Krumwiede, ${ }^{\ddagger}$ Debra Johnson, ${ }^{\ddagger}$ \\ and Craig Henke* \\ *Department of Medicine, ${ }^{\ddagger}$ Department of Pediatrics, and ${ }^{\S}$ Department of Laboratory Medicine and Pathology, University of Minnesota, \\ Minneapolis, Minnesota 55455
}

\begin{abstract}
Fibrosis results when myofibroblasts invade the wound fibrin provisional matrix. Extracellular matrix receptors on the cell surface mediate cell adhesion, migration, and invasion. Recent work with transformed cells indicates that these cells use the cell surface matrix receptor CD44 for migration and invasion. In this study, we examine whether lung fibroblasts, isolated from patients dying with acute alveolar fibrosis, use CD44 to invade a fibrin matrix. Consistent with a role for CD44 in mediating fibroblast invasion and subsequent tissue fibrosis, immunohistochemical analysis of lung tissue from patients who died from acute alveolar fibrosis after lung injury reveals CD44-expressing mesenchymal cells throughout newly formed fibrotic tissue. PCR, Western, and immunoprecipitation analysis demonstrate that the $85-\mathrm{kD}$ CD44 isoform is expressed by acute lung injury fibroblasts. Consistent with a role in mediating matrix adhesion and migration ultrastructurally, CD44 was found uniformly over the cell surface and was found densely labeling filopodia and lamellipodia, highly motile structures involved in cell migration. To determine if lung injury fibroblasts use CD44 to invade fibrin, a fibrin gel model of fibrosis was used. By blocking the function of CD44 with monoclonal antibodies, fibroblast invasion into a fibrin matrix was inhibited. To examine the mechanism by which CD44 mediates fibroblast invasion, the role of CD44 in fibroblast migration and adhesion was evaluated. Anti-CD44 antibody blocked fibroblast migration on the provisional matrix proteins fibronectin, fibrinogen, and hyaluronic acid. Additionally, fibroblast CD44 mediated adhesion to the provisional matrix proteins fibronectin, fibrin, and hyaluronic acid, but not to laminin, a component of the basement membrane. These findings support the hypothesis that fibroblast CD44 functions as an adhesion receptor for provisional matrix proteins and is capable of mediating fibroblast migration and invasion of the wound provisional matrix resulting in the formation of fibrotic tissue. (J. Clin. Invest. 1996. 98:1713-1727.) Key words: lung fibrosis • airspace provisional matrix $\bullet$ fibroblast migration $\bullet$ CD44 $\bullet$ apoptosis
\end{abstract}

Address correspondence to Craig A. Henke, Pulmonary and Critical Care Division, Department of Medicine, UMHC Box 276, University of Minnesota, 420 Delaware Street SE, Minneapolis, MN 55455. Phone: 612-624-0999; FAX: 612-625-2174.

Received for publication 10 October 1995 and accepted in revised form 31 July 1996.

J. Clin. Invest.

(C) The American Society for Clinical Investigation, Inc.

0021-9738/96/10/1713/15 \$2.00

Volume 98, Number 8, October 1996, 1713-1727

\section{Introduction}

The biological process of fibrosis occurs in response to various stimuli in many biological systems. During some repair processes, such as cutaneous wound healing, fibrosis functions as a necessary homeostatic mechanism. In other cases, however, fibrosis may occur at critical anatomic sites, thereby adversely affecting organ function.

One example of pathological fibrosis is pulmonary alveolar fibrosis after acute lung injury. The pathophysiological process characteristic of acute lung injury begins with an inflammatory insult to the alveolar wall. As a result, plasma-derived fluid flows through the disrupted alveolar wall and into the airspaces where plasma fibrinogen becomes clotted to crosslinked fibrin, entrapping plasma proteins such as fibronectin in solid phase (1). In response to migration and growth-promoting signals present within the fibrin provisional matrix, myofibroblasts and endothelial cells invade the airspace, divide, and form intraalveolar granulation tissue $(2,3)$. This can lead to obliteration of the gas exchange apparatus with fibrotic tissue and subsequent respiratory insufficiency.

The molecular basis for fibroblast migration and invasion into the fibrin matrix during wound and tissue repair is not fully understood. In general, cells adhere and migrate on extracellular matrix components via cell surface matrix receptors that bind distinct domains on extracellular matrix proteins. One such receptor, RHAMM, has been implicated in facilitating fibroblast migration on hyaluronan (4). Studies examining the molecular basis of tumor cell migration and invasion have identified another surface receptor, chondroitin sulfate proteoglycan (CSPG) ${ }^{1}$ containing CD44 as its core protein, as important in tumor cell migration and invasion. In studies of melanoma cells, CD44-related CSPG has been shown to play a role in mediating melanoma cell invasion of type I collagen gels (5). Furthermore, studies on tumor cells linking the transmembrane glycoprotein CD44 with cell motility demonstrate that the expression of specific splice variants of CD44 correlate with metastatic potential in model systems of rat pancreatic carcinoma $(6,7)$. In addition, overexpression of CD44 cDNA in tumor cells has correlated with increased cell motility, enhanced tumor growth, and metastatic proclivity in nude mice $(8,9)$.

Several lines of evidence link CD44 with fibroblast adhesion and migration and the development of fibrosis. First, CD44 is a cell surface matrix receptor for several extracellular matrix components including hyaluronic acid and fibronectin $(10,11)$. Second, elevated levels of fibronectin and hyaluronic acid accumulate in the fibrin provisional matrix and have been

1. Abbreviations used in this paper: CSPG, chondroitin sulfate proteoglycan; RT, reverse transcription. 
recovered from the air-lung interface after the onset of acute lung injury (12-15). Importantly, fibronectin, fibrin, and hyaluronan support cell motility (16-19). Third, cell surface CD44 expression has been found to be increased in hypertrophic scar fibroblasts derived from human cutaneous scar tissue as compared to normal skin fibroblasts (20). Collectively, these data suggest that CD44 may be an important cell surface adhesion receptor capable of mediating fibroblast migration and invasion into the wound provisional matrix during tissue repair. However, no data exists that directly identifies this cell surface matrix receptor with fibroblast invasion, either ex vivo or in vivo. Our objective in the present study was to develop such data.

To determine if CD44 is an important matrix receptor capable of mediating fibroblast migration and invasion into the fibrin provisional matrix during tissue repair, we have examined fibroblasts isolated from patients dying from the fibroproliferative disorder of acute alveolar fibrosis after lung injury. Immunohistochemical analysis of lung tissue derived from patients with acute lung injury revealed CD44-expressing mesenchymal cells throughout newly formed fibrotic tissue in the injured lung. PCR, Western, and immunoprecipitation analysis demonstrate that acute lung injury fibroblasts express the $85-\mathrm{kD}$ isoform of CD44. Consistent with a role in adhesion and migration ultrastructurally, CD44 was found on filopodia and lamellipodia and could be found at the leading edge of migrating fibroblasts. By blocking CD44 function with an anti-CD44 antibody, acute lung injury fibroblast adhesion and migration on fibronectin, fibrinogen, hyaluronic acid, and invasion into fibrin gels was inhibited. Collectively, these results are consistent with the hypothesis that CD44 is a cell surface matrix adhesion receptor involved in mediating fibroblast invasion of the fibrin provisional matrix during tissue repair.

\section{Method}

\section{Source of lung mesenchymal cells}

Five primary cultures of lung mesenchymal cells were developed from the lungs of patients with severe acute lung injury (adult respiratory distress syndrome) as previously described (21):

Source of tissue for histological analysis and isolation of lung mesenchymal cells $(n=3)$. This group consisted of lungs from patients who died from respiratory failure 14, 21, and $30 \mathrm{~d}$ after disease onset and who met established criteria for the adult respiratory distress syndrome $(22,23)$. Histological analysis of each lung specimen revealed diffuse alveolar damage and intraalveolar fibrosis.

Additional source of lung mesenchymal cells $(n=2)$. Primary mesenchymal cell cultures were developed from an additional two patients with severe acute lung injury being supported with mechanical ventilation who met the standard criteria for adult respiratory distress syndrome. Patients in this cohort underwent bronchoscopy with bronchoalveolar lavage for purposes of obtaining mesenchymal cells from the alveolar air-lung interface. These patients had bronchoalveolar lavage performed 14-28 d after disease onset, which correlates with the fibroproliferative phase of adult respiratory distress syndrome.

\section{Source of normal fibroblasts}

One diploid fibroblast strain, normal lung fibroblasts (210; American Type Culture Collection, Rockville, MD) was also used. Cell cultures were stored frozen until ready for use. The normal lung fibroblasts were maintained in culture $\left(37^{\circ} \mathrm{C}, 10 \% \mathrm{CO}_{2}\right)$ in DMEM containing $10 \%$ heat-inactivated fetal calf serum, subcultivated weekly and used before the eighth subcultivation. Normal lung fibroblasts in culture were used for subsequent experiments at $50-75 \%$ of their saturation density unless otherwise specified.

\section{Preparation of mesenchymal cell cultures}

Mesenchymal cell primary cultures were developed from the lungs of patients who died from respiratory failure after onset of lung injury by enzymatic and mechanical dispersion of lung tissue in a manner designed to optimize viability and yield as previously described $(n=$ 3) (21). Cultures were stored frozen until ready for use and subcultivation was performed weekly. Lung injury cells were used for subsequent experiments at $50-75 \%$ of their saturation density unless otherwise specified, and before the 12th subcultivation.

Primary cultures of airspace mesenchymal cells were isolated from bronchoalveolar lavage fluid $(n=2)$. Briefly, the lavage fluid was centrifuged $\left(10 \mathrm{~min}, 1,300 \mathrm{~g}, 20^{\circ} \mathrm{C}\right)$, resuspended in DMEM with $10 \%$ heat-inactivated fetal calf serum, and plated on 100-mm tissue culture dishes (Falcon 3003; Becton Dickinson Labware, Lincoln Park, NJ). These cells were refed three times a week and first passaged after several confluent colonies larger than a high power field were observed. Cultures were stored frozen until ready for use and subcultivation was then performed weekly. Airspace lung injury mesenchymal cells were used within 12 passages for subsequent experiments at $50-75 \%$ of their saturation density unless otherwise specified.

\section{Characterization of recovered cells}

The cells of both populations were characterized by morphological and immunohistochemical criteria as previously described (21). Morphologically by phase contrast, the cells demonstrated the typical spindle shaped appearance of lung fibroblasts and ultrastructurally, the characteristic features of myofibroblasts were observed. Immunohistochemical analysis indicated that the cells displayed determinants characteristic of mesenchymal cells (vimentin, $\alpha$-smooth muscle actin, and desmin), but did not display determinants of endothelial cells (Factor VIII and ulex), epithelial cells (cytokeratin and epithelial membrane antigen), or leukocytes (CD45). In addition, acute lung injury mesenchymal cells displayed prominent transverse actin fibers, a feature of migrating cells, by rhodamine phalloidin staining.

\section{Immunohistochemical staining for CD44}

Immunohistochemical studies were performed on frozen sections prepared from lung specimens obtained from patients who died of acute alveolar fibrosis and from surgical specimens showing normal lung parenchyma. The avidin-biotin complex immunoperoxidase technique was used. The sections were incubated overnight $(16 \mathrm{~h})$ with anti-CD44 antibody (BU52; The Binding Site, Inc., San Diego, CA) at a 1:4,000 dilution. As controls, nonimmune mouse serum and an $\mathrm{IgG}_{1}$ isotype-matched control antibody (mouse $\mathrm{IgG}_{1}$ Kappa; Sigma Chemical Co., St. Louis, MO) were used. Negative controls consisted of lung tissue from acute lung injury patients incubated with an "irrelevant" primary antibody (antisynaptophysin antibody, 1:70 dilution; Boehringer-Mannheim Biochemicals, Indianapolis, IN) and secondary antibody without primary antibody.

\section{Reverse transcriptase- $P C R$}

cDNA for PCR was synthesized by a random primer method as described by Bennett et al. (24). $1 \mu \mathrm{g}$ of fibroblast total mRNA was incubated $\left(5 \mathrm{~min}, 75^{\circ} \mathrm{C}\right.$ ) with $2 \mu \mathrm{l}$ of $0.1 \mathrm{M}$ Hexamer (Gibco Laboratories, Grand Island, NY). Subsequently, $4 \mu 1$ of $5 \times$ first strand buffer (Gibco Laboratories), $0.5 \mu \mathrm{l}$ of 0.1 M DTT, $1 \mu \mathrm{l}$ of each $10 \mathrm{mM}$ dNTPs, and $1 \mu \mathrm{l}$ of Superscript Plus (Gibco Laboratories) were added to diethyl procarbonate-treated water to a final volume of 20 $\mu l$. The mixture was incubated $\left(1 \mathrm{~h}, 37^{\circ} \mathrm{C}\right)$ and enzyme inactivated $(5$ $\min , 95^{\circ} \mathrm{C}$ ). PCR reactions were carried out in a total volume of 100 $\mu \mathrm{l}$ containing $20 \mu \mathrm{l}$ of cDNA, $8 \mu \mathrm{l}$ of each $10 \mathrm{mM}$ dNTPs, $1 \mu \mathrm{l}$ of 20 $\mathrm{pmol} / \mathrm{ml}$ of each primer, $8 \mu \mathrm{l} 10 \times \mathrm{PCR}$ buffer, and $2.5 \mathrm{U}$ Taq polymerase (Fisher Scientific Co., Pittsburgh, PA). Primers were added when the reaction mixture was at $95^{\circ} \mathrm{C}$. The cDNA was amplified for 22 cycles. The PCR amplification program was as follows: denatur- 
ation $\left(0.5 \mathrm{~min}, 95^{\circ} \mathrm{C}\right)$, annealing $\left(1.5 \mathrm{~min}, 62^{\circ} \mathrm{C}\right)$, extension $(1 \mathrm{~min}$, $\left.73^{\circ} \mathrm{C}\right)$, followed by a final extension $\left(10 \mathrm{~min}, 73^{\circ} \mathrm{C}\right)$. The oligonucleotides used as PCR primers were the CD44E3-FP and the CD44E16-RP primers as described by Bennett et al. (24). The CD44 variant exon primers were the pv2-pv10 primers as described by van Weering et al. (25).

\section{Western analysis}

Western analysis of both lung injury and normal fibroblasts were performed as previously described (3). Briefly, fibroblasts were washed, lysed on ice with lysis buffer (PBS, $1 \%$ Triton X-100, $0.5 \%$ sodium deoxycholate, $1 \mathrm{mM}$ PMSF), and some aliquots of lysate supernatant were digested $\left(37^{\circ} \mathrm{C}, 4 \mathrm{~h}\right)$ with chondroitinase $\mathrm{ABC}(0.1 \mathrm{U} / \mathrm{ml}$; Seikagaku America, Inc., Rockville, MD) before electrophoresis. Proteins were subjected to SDS-PAGE 6-15\% under nonreducing conditions and electrophoretically transferred $(45 \mathrm{~min}, 24 \mathrm{~V})$ to a $0.2-\mu \mathrm{m}$ nitrocellulose membrane. Membranes were blocked in $10 \%$ dry milk in TTBS (150 mM NaCl, $100 \mathrm{mM}$ Tris, $0.05 \%$ Tween 20 ), incubated with either mouse anti-human CD44 antibody (Hermes 3, a gift from Dr. Eugene Butcher, Stanford University School of Medicine, Stanford, CA, or BU52; The Binding Site), rat anti-human CD44 antibody (Hermes 1, a gift from Dr. Eugene Butcher), or rat anti-mouse CD44 antibody (IM7; PharMingen, San Diego, CA), washed and then incubated with the appropriate secondary antibody (goat antimouse or goat anti-rat IgG antibody) coupled to horseradish peroxidase and color developed. Controls consisted of nitrocellulose membranes incubated with normal mouse serum followed by the anti-mouse IgG secondary antibody.

\section{Immunoprecipitation and SDS-PAGE}

Acute lung injury fibroblasts were released with trypsin-EDTA, washed, resuspended to a final concentration of $10^{7}$ cells $/ \mathrm{ml}$ in PBS, $\mathrm{pH} 7.4$, and placed on ice. The cells were surface labeled by the addition of $5 \mathrm{mCi}{ }^{125} \mathrm{I}$ to the cell suspension containing lactoperoxidase (460 U/ml final concentration) and $\mathrm{H}_{2} \mathrm{O}_{2}(0.0017 \%$ final concentration) and mixed $\left(3 \mathrm{~min}, 4^{\circ} \mathrm{C}\right)$. The surface-labeled cells were washed, lysed $\left(30 \mathrm{~min}, 4^{\circ} \mathrm{C}\right)$ in a solubilization buffer $(50 \mathrm{mM}$ Tris- $\mathrm{HCl}, \mathrm{pH} 7.4$, $50 \mathrm{mM} n$-octyl $\beta$-D glucopyranoside, $15 \mathrm{mM} \mathrm{NaCl}, 1 \mathrm{mM} \mathrm{CaCl}_{2}, 1 \mathrm{mM}$ $\mathrm{MgCl}_{2}, 1 \mathrm{mM} \mathrm{MnCl} 2,1 \mathrm{mM}$ PMSF, $1 \mathrm{mM} n$-ethyl maleimide, $100 \mu \mathrm{g} /$ $\mathrm{ml}$ soybean trypsin inhibitor, and $100 \mu \mathrm{g} / \mathrm{ml}$ leupeptin), and ultracentrifuged $\left(36,500 \mathrm{rpm}, 60 \mathrm{~min}, 4^{\circ} \mathrm{C}\right)$ to remove insoluble material. The cell lysate was first precleared $\left(3 \mathrm{~h}, 4^{\circ} \mathrm{C}\right)$ with rabbit anti-mouse IgG (Pel-Freeze Biologicals, Rogers, AR) coupled to protein A agarose beads, and then incubated $\left(12 \mathrm{~h}, 4^{\circ} \mathrm{C}\right)$ with either Hermes 3 or BU52 anti-CD44 monoclonal antibody coupled to rabbit anti-mouse IgG protein A agarose beads and washed. Since CD44 may be modified by the addition of chondroitin sulfate sidechains to its extracellular domain, aliquots of labeled protein were digested with chondroitinase $\mathrm{ABC}$ before immunoprecipitation. Additional aliquots of precleared cell lysates were incubated with two other monoclonal antibodies (ICN Biomedicals Inc., Irvine, CA) that recognize the unsaturated bonds of either the 4- or 6-sulfated chondroitin sulfate residues that remain attached to the proteoglycan core protein after chondroitinase $\mathrm{ABC}$ digestion. Gel sample buffer was added to the washed beads and boiled ( $5 \mathrm{~min}$ ). To visualize CD44 containing chondroitin sulfate and CSPG core protein by autoradiography, ${ }^{125} \mathrm{I}$ labeled proteins in the supernatant were digested with chondroitinase $\operatorname{ABC}\left(0.1 \mathrm{U} / \mathrm{ml}, 37^{\circ} \mathrm{C}, 4 \mathrm{~h}\right)$ and both digested and undigested samples were analyzed by $6-15 \%$ SDS-PAGE under nonreducing conditions. The gels were dried and used for autoradiography using XAR-5 film (Eastman Kodak Co., Rochester, NY).

\section{Immunocytochemical localization of CD44}

For immunocytochemical localization of CD44, acute lung injury fibroblasts were released with trypsin-EDTA, washed, and plated $(24 \mathrm{~h})$ on two-chamber glass slides (Lab-Tek; Nunc Inc., Naperville, IL) coated with $10 \mathrm{mg} / \mathrm{ml}$ fibronectin. The cells were rinsed two times with $\mathrm{PBS}\left(37^{\circ} \mathrm{C}\right)$ and fixed with $1 \%$ paraformaldehyde and $0.05 \%$ glutaraldehyde $\left(10 \mathrm{~min}, 22^{\circ} \mathrm{C}\right)$. The fixation was quenched with $0.1 \mathrm{M}$ glycine $\left(5 \mathrm{~min}, 22^{\circ} \mathrm{C}\right)$, and the cells were blocked with PBS $+10 \%$ calf serum. A mouse anti-human CD44 antibody (BU52) was suspended in PBS $+10 \%$ calf serum and applied to the cells (30 min, $22^{\circ} \mathrm{C}$ ). The cells were then rinsed three times with PBS, and a fluorescein-conjugated goat anti-mouse IgG antibody (Jackson ImmunoResearch Labs Inc., West Grove, PA) was applied $\left(20 \mathrm{~min}, 22^{\circ} \mathrm{C}\right)$. The rinsed samples were mounted with coverslips and observed on an $\mathrm{Ax}$ iophot photomicroscope (Carl Zeiss, Inc., Thornwood, NY). Controls consisted of substituting normal mouse serum for the primary antibody and mouse $\mathrm{IgG}_{1}$ isotype-matched control monoclonal antibody and incubating cells with secondary antibody only.

\section{Immunoelectron microscopic localization of CD44}

For localization of CD44 at the ultrastructural level, fibroblasts were released with trypsin-EDTA, washed, and allowed to adhere $(18 \mathrm{~h}$, $37^{\circ} \mathrm{C}$ ) to formavar-coated carbon stabilized grids that had been incubated with fibronectin $(10 \mu \mathrm{g} / \mathrm{ml})$. The grids were rinsed with PBS and fixed with $1 \%$ paraformaldeheyde and $0.05 \%$ glutaraldehyde $(10$ $\min , 22^{\circ} \mathrm{C}$ ). The grids were again rinsed, and the fixation was quenched with $0.1 \mathrm{M}$ glycine $\left(5 \mathrm{~min}, 22^{\circ} \mathrm{C}\right)$. The grids were then blocked with $10 \%$ calf serum in $\operatorname{PBS}\left(5 \mathrm{~min}, 22^{\circ} \mathrm{C}\right)$, and then incubated with a mouse anti-human CD44 antibody (BU52), suspended in PBS $+10 \%$ calf serum $\left(30 \mathrm{~min}, 22^{\circ} \mathrm{C}\right)$. The grids were then rinsed three times with PBS and incubated $(20 \mathrm{~min})$ with a goat anti-mouse antibody coupled to $30 \mathrm{~nm}$ gold (Amersham Corp., Life Sciences, Arlington Heights, IL). The grids were rinsed thoroughly with distilled $\mathrm{H}_{2} 0$, allowed to air dry, and were visualized on an electron microscope (301; Phillips Electronic Instrs. Co., Mahwah, NJ). Controls consisted of cells incubated with normal mouse serum and mouse $\mathrm{IgG}_{1}$ isotype-matched control monoclonal antibody.

\section{Invasion gels}

Gels composed of fibrin were prepared under sterile conditions as previously described by Brown et al. (17). Cultures of acute lung injury fibroblasts were harvested with trypsin-EDTA, washed, and resuspended in DMEM with $20 \%$ heat-inactivated calf serum at a final concentration of $10^{6}$ cells $/ \mathrm{ml}$. Six microdroplets of $2 \mu \mathrm{l}$ of the cell suspension were spotted on the bottom of a Falcon six-well plate (Becton-Dickson \& Co.) and cells were allowed to adhere $\left(4 \mathrm{~h}, 37^{\circ} \mathrm{C}\right)$ in a humidified incubator. Nonadhering cells were washed from the plate with PBS. Human thrombin $(0.2 \mathrm{U} / \mathrm{ml}$, Sigma Chemical Co. $)$ was added to HPLC-DEAE-purified human fibrinogen $(3 \mathrm{mg} / \mathrm{ml}$, Sigma Chemical Co.) dissolved in a Hepes-saline buffer $(0.13 \mathrm{M}$ $\mathrm{NaCl}, 0.025 \mathrm{M} \mathrm{N}$-2-hydroxyethylpiperazine- $N$ '-2-ethansulfonic acid, $0.005 \mathrm{M} \mathrm{CaCl}_{2}, \mathrm{pH}$ 7.4). This mixture was layered over the adherent cells and allowed to solidify $\left(30 \mathrm{~min}, 37^{\circ} \mathrm{C}\right)$. Finally, $1 \mathrm{ml}$ DMEM containing $2.5 \%$ heat-inactivated calf serum was added to cover the fibrin gel. The gels were incubated $\left(37^{\circ} \mathrm{C}, 10 \% \mathrm{CO}_{2}\right)$ in a humidified incubator, and the cells were refed three times each week with fresh media.

Cell invasion was measured by quantifying the number of cells that invaded the overlying fibrin gel. By focusing on the bottom of the plate and then refocusing above this plane using an inverted phase contrast microscope (IMT-2; Olympus Corp., Lake Success, NY), cells that had invaded the gel could be identified clearly by their position above the original starting plane. Quantification of the number of invading cells was performed on days $1-7$. Results are reported as mean number of cells invading the gel/microdroplet plus or minus the standard error of the mean of at least six microdroplets.

\section{Cell adhesion and migration assays}

Cell adhesion to protein-coated substrata was performed as previously described $(2,16)$ using $0.1-100 \mu \mathrm{g} / \mathrm{ml}$ fibronectin, $0.005-5 \mu \mathrm{M}$ fibrinogen, $3 \mathrm{mg} / \mathrm{ml}$ fibrin, $5 \mu \mathrm{g} / \mathrm{ml}-5 \mathrm{mg} / \mathrm{ml}$ hyaluronic acid, and $1-50$ $\mu \mathrm{g} / \mathrm{ml}$ laminin. Briefly, for the adhesion assays, acute lung injury fibroblasts, $50-75 \%$ confluent, were radiolabeled $(18 \mathrm{~h})$ with $\left[{ }^{3} \mathrm{H}\right]$ thymidine $(2 \mathrm{mCi} / \mathrm{ml})$, released with trypsin-EDTA (Gibco Laboratories), washed and resuspended to a final concentration of $5 \times 10^{4}$ 


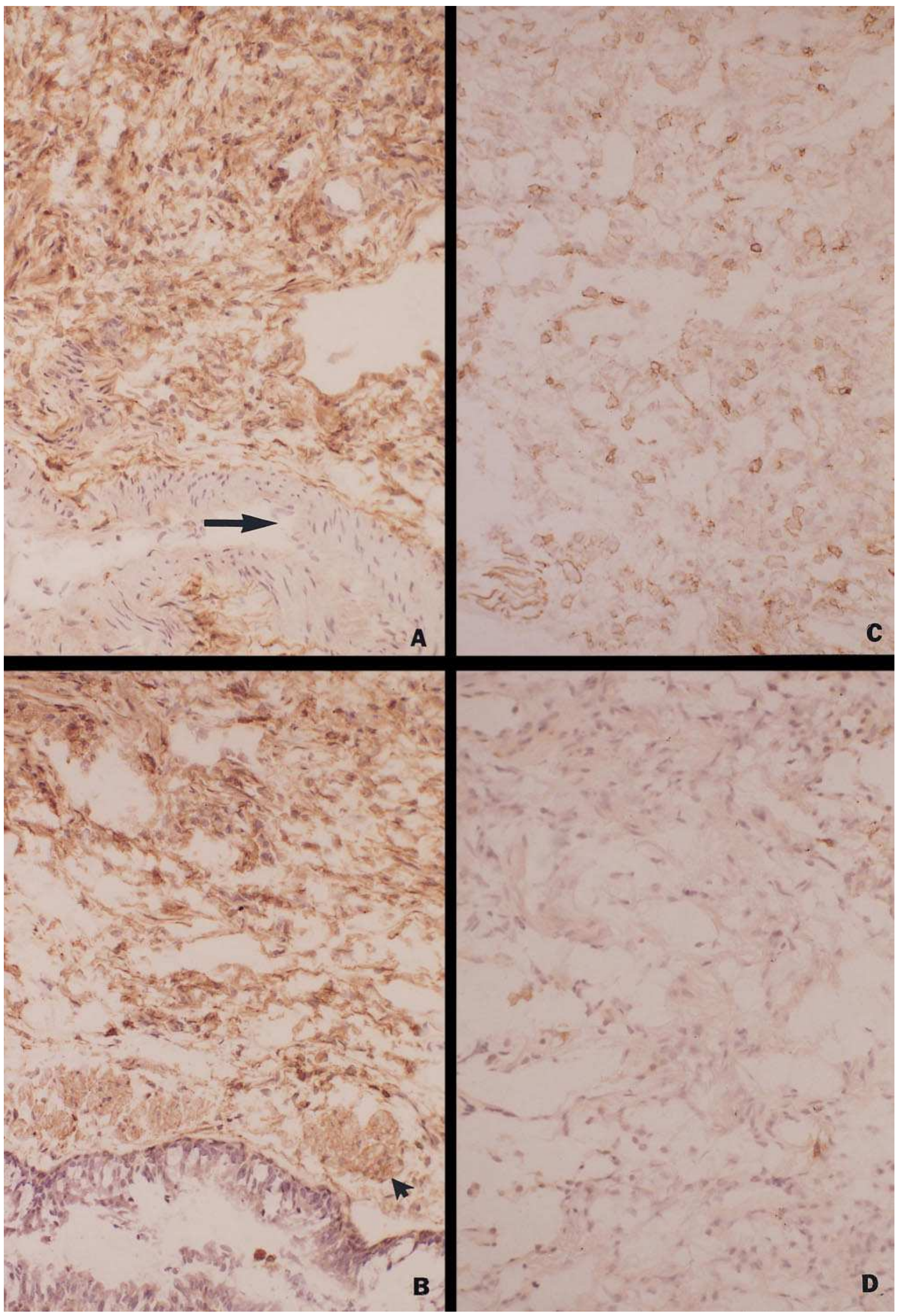


cells $/ \mathrm{ml}$ in DMEM with $5 \mathrm{mg} / \mathrm{ml}$ BSA. $5 \times 10^{3}$ cells/well were added in $100-\mu l$ aliquots to protein-coated substrata and allowed to adhere $(1 \mathrm{~h})$. After gentle washing, adherent cells were solubilized in $150 \mu \mathrm{l}$ of $0.5 \mathrm{~N} \mathrm{NaOH}$ containing $1 \%$ SDS, and radioactivity was quantified with a liquid scintillation counter (LS 7500; Beckman Instruments, Inc., Brea, CA).

Cell migration was assayed in 48-well modified Boyden chambers (NeuroProbe, Bethesda, MD) as previously described (2). Briefly, the undersides of $8-\mu \mathrm{m}$ pore size polyvinyl pyrrolidone-free polycarbonate filters (Nucleopore Corp., Pleasonton, CA) were precoated with fibronectin $(1-10 \mathrm{mM})$, fibrinogen $(0.5-5 \mathrm{mM})$, or hyaluronic acid $(50 \mu \mathrm{g} / \mathrm{ml}-5 \mathrm{mg} / \mathrm{ml})$. The lower wells of the modified Boyden chamber were filled with DMEM containing $5 \mathrm{mg} / \mathrm{ml} \mathrm{BSA}$. Acute lung injury fibroblasts, $50-75 \%$ confluent, were released with trypsinEDTA, and resuspended in DMEM with $5 \mathrm{mg} / \mathrm{ml} \mathrm{BSA}$ at a concentration of $10^{6} \mathrm{cells} / \mathrm{ml}$. These cells were added to the upper wells at $4.5 \times$ $10^{4}$ cells/well and migration to the underside of the filters was measured after $4 \mathrm{~h}$ at $37^{\circ} \mathrm{C}$.

\section{Inhibition assays: anti-CD44 monoclonal antibody}

Inhibition assays using a mouse anti-human CD44 monoclonal antibody (BU52; The Binding Site, Inc.) were performed as previously described (26). Briefly, for the adhesion assay, radiolabeled cells were preincubated with serial dilutions of the antibody $\left(30 \mathrm{~min}, 37^{\circ} \mathrm{C}\right)$. Cells were added to the extracellular matrix protein-coated plates and incubated $\left(1 \mathrm{~h}, 37^{\circ} \mathrm{C}\right)$. The wells were washed and adherent cells quantified as for the cell adhesion assays, as described above.

For the migration assay, acute lung injury fibroblasts were preincubated $\left(30 \mathrm{~min}, 37^{\circ} \mathrm{C}\right)$ with serial dilutions of the anti-CD44 antibody and added to the upper wells of the modified Boyden chambers as described above.

For the invasion assay, the cells were allowed to attach to the surface of the tissue culture plate for $4 \mathrm{~h}$, and then overlayed with fibrinogen and allowed to clot by the addition of thrombin for an additional hour. Then serial dilutions of the monoclonal antibody were added to the media used to feed the cells.

Control assays were performed by substituting an isotype-matched control monoclonal antibody (mouse $\mathrm{IgG}_{1}$ Kappa), normal mouse $\mathrm{IgG}$ and anti- $\alpha_{2}$ integrin monoclonal antibody (Chemicon International, Inc., Temecula, CA) for the anti-CD44 monoclonal antibody.

\section{$\beta$-D xyloside and chondroitinase ABC pretreatment}

For adhesion, migration, and invasion assays, cells were treated with $1 \mathrm{mM} \beta$-D xyloside ( $p$-nitrophenyl- $\beta$-D-xylopyranoside; Sigma Chemical Co.) for $48 \mathrm{~h}$ to inhibit CSPG synthesis by replacing the medium of cell cultures with DMEM containing $2.5 \%$ heat-inactivated calf serum, with or without $\beta$-D xyloside. $\beta$-D xyloside was also included in the medium during the assays. For invasion assays, fibrin gels used in the $\beta$-D xyloside experiments were composed of fibrinogen dissolved in Hepes-saline buffer containing $\beta$-D xyloside.

For chondroitinase $\mathrm{ABC}$ treatment, cells were pretreated with varying concentrations $(0.1-0.5 \mathrm{U} / \mathrm{ml})$ of chondroitinase $\mathrm{ABC}(15$ min, $37^{\circ} \mathrm{C}$, Sigma Chemical Co.) before adhesion and migration assays as described by Faassen et al. (5). Chondroitinase ABC was also included in the cell medium during the adhesion and migration assays.

Hyaluronidase treatment of fibrinogen, fibronectin, and fibrin gels

Human fibrinogen $(3 \mathrm{mg} / \mathrm{ml})$ was dissolved in Hepes-saline buffer containing 20 turbidity reducing units/ml of Streptomyces hyalu- ronidase (Calbiochem-Behring Corp., San Diego, CA) and incubated $\left(3 \mathrm{~h}, 37^{\circ} \mathrm{C}\right)$. Human thrombin $(0.2 \mathrm{U} / \mathrm{ml})$ was added to the hyaluronidase-treated fibrinogen solution and this mixture was then layered over adherent fibroblasts and allowed to solidify $\left(30 \mathrm{~min}, 37^{\circ} \mathrm{C}\right)$. $1 \mathrm{ml}$ of DMEM containing $2.5 \%$ heat-inactivated calf serum was added to cover the gels, which were incubated as described above.

For adhesion and migration assays, solutions of fibrinogen and fibronectin were pretreated with 20 turbidity reducing units $/ \mathrm{ml}$ of Streptomyces hyaluronidase $\left(3 \mathrm{~h}, 37^{\circ} \mathrm{C}\right)$ before coating the tissue culture plastic or polycarbonate filters, respectively.

\section{Statistical analysis}

All the data were expressed as mean \pm SEM performed in triplicate unless otherwise indicated.

\section{Results}

Immunohistochemistry. To link CD44 with the development of tissue fibrosis, one would predict that fibroblasts comprising newly formed fibrotic tissue would express CD44. Immunohistochemical analysis of lung tissue obtained from patients who died from the fibroproliferative disorder of acute alveolar fibrosis after lung injury was performed to examine the spatial distribution and anatomic location of CD44-expressing mesenchymal cells. Sheets of actively proliferating spindle (mesenchymal) cells expanding the interstitium and penetrating into alveolar spaces were strongly immunoreactive with anti-CD44 antibody (Fig. 1, $A$ and $B$ ). Immunoreactivity was also found in intraalveolar macrophages and bronchial/bronchiolar smooth muscle, but not vascular smooth muscle. Normal control lung immunostained with anti-CD44 antibody showed positive staining for macrophages and a lack of immunoreactivity in the interstitium (Fig. $1 C$ ). In contrast, fibrotic lung stained with an $\mathrm{IgG}$ isotype-matched control antibody did not show any immunoreactive cells (Fig. 1 D). Normal control lung stained with the $\mathrm{IgG}$ isotype-matched control antibody also did not show immunoreactive cells (data not shown). In addition, normal and acute lung injury lung tissue did not show CD44 immunoreactivity when the anti-CD44 primary antibody was omitted and an "irrelevant" antibody (antisynaptophysin) was substituted in its place (data not shown). Also, no immunoreactivity was seen when fibrotic and normal lung tissue were stained with secondary antibody without primary antibody (data not shown).

Analysis of CD44 $\mathrm{mRNA}$ transcripts in acute lung injury fibroblasts. Reverse transcription (RT)-PCR was performed to determine which mRNA transcripts corresponding to different CD44 isoforms were present in acute lung injury and normal fibroblasts. RT-PCR using primers located in the common exons E3 and E16 generated one PCR product of $\sim 450$ bp (Fig. 2, lane 1) using mRNA from either acute lung injury or normal fibroblasts (data shown for acute lung injury fibroblasts only). The $\sim 450$-bp product is the predicted size (469 bp) for the "standard" isoform of CD44 (CD44H), which corresponds to the $85-\mathrm{kD}$ CD44 protein.

Figure 1. CD44-expressing mesenchymal cells are found throughout newly formed fibrotic lung tissue obtained from patients who died from the fibroproliferative disorder of acute alveolar fibrosis after lung injury. ( $A$ and $B$ ) Lung tissue obtained immediately after death was snap frozen and immunostained with anti-CD44 monoclonal antibody. Strong immunoreactivity was detected in actively proliferating interstitial and intraalveolar spindle (mesenchymal) cells that obliterated the normal alveolar architecture. Vascular smooth muscle cells were negative $(A$, long arrow); however, a positive staining pattern was observed in airway-associated smooth muscle $(B$, arrowhead). ( $C$ ) Normal control lung immunostained with anti-CD44 antibody showed positive staining for intraalveolar macrophages. $(D)$ Fibrotic lung stained with an IgG isotypematched control antibody showed a lack of immunoreactivity (avidin-biotin-complex/hematoxylin stain, $50 \times$ ). 


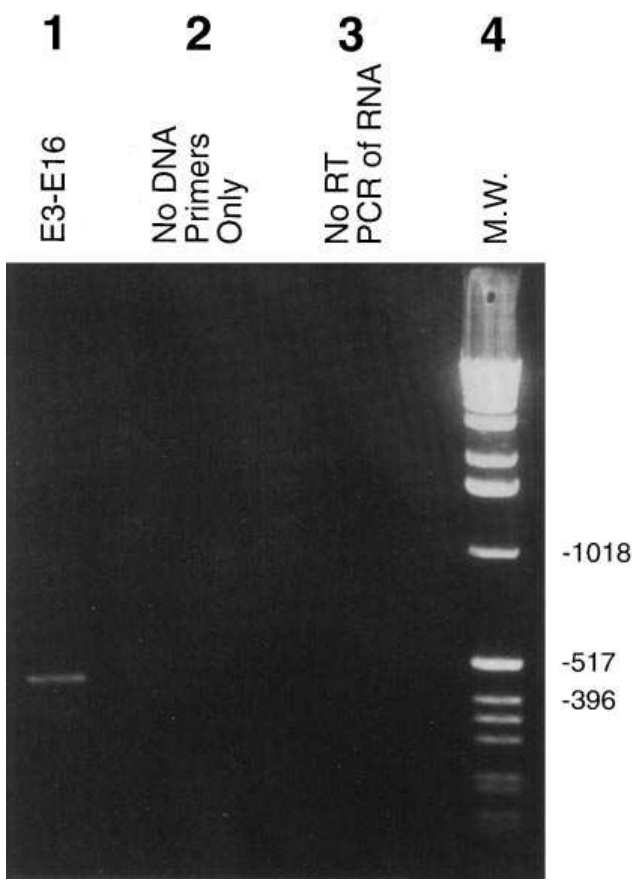

Figure 2. Expression of CD44 RNA transcripts in acute lung injury fibroblasts. RT-PCR was performed on mRNA obtained from acute lung injury fibroblasts. PCR products were fractionated on a $2 \%$ agarose gel and stained with ethidium bromide. Lane 1 contains the PCR product for the constant to constant exon primers (E3-E16). (Lane 2) Negative control consisting of PCR primers only (no DNA). (Lane 3) Negative control consisting of PCR of RNA (no reverse transcriptase reaction). Lane 4 contains the 1 -kb DNA ladder.

RT-PCR was also used to examine for expression of CD44 transcripts containing variant exons. As expected based on the PCR results using primers located in the common exons showing only one band, no PCR products were apparent when PCR anal- ysis was performed using the variant exon primers pv2-pv10 as forward primers and the E16 PCR primer as the reverse primer (data not shown). Negative controls consisting of PCR of primers only (no DNA) and PCR of RNA (no reverse transcriptase reaction) yielded no PCR products (Fig. 2, lanes 2 and 3). These data indicated that both normal and acute lung injury fibroblasts express mRNA for the 85-kD isoform of CD44.

Acute lung injury fibroblast CD44 analysis. To identify the presence and determine the molecular mass of acute lung injury and normal fibroblast CD44, Western analysis of cell lysates and immunoprecipitation of ${ }^{125}$ I surface-labeled proteins using a mouse anti-human CD44 monoclonal antibody were performed. Since CD44 may be modified by the addition of chondroitin sulfate sidechains to the extracellular domain of the core protein, aliquots of the cell lysates (Western analysis) and ${ }^{125}$ I surface-labeled proteins (immunoprecipitation) were digested by chondroitinase $\mathrm{ABC}$ before electrophoresis. The undigested and chondroitinase $\mathrm{ABC}$-digested cell lysates and immunoprecipitated ${ }^{125}$ I-labeled proteins were analyzed by 6-15\% SDS-PAGE under nonreducing conditions.

Western analysis of undigested and digested cell lysates from both acute lung injury and normal fibroblasts revealed the presence of a broad region of immunoreactivity ranging from $\sim 85$ to $97 \mathrm{kD}$ (Fig. $3 A$, lanes $A-D$ ). Data is shown for Hermes 3 (mouse anti-human CD44 antibody) only. Similar results were obtained using Hermes 1, IM7, and BU52 monoclonal antibodies (rat anti-human, rat anti-mouse, and mouse anti-human CD44 antibodies). This data is consistent with the PCR analysis showing the presence of the 450-bp PCR product that corresponds to the $\sim 85-95-\mathrm{kD}$ CD 44 protein. No immunoreactivity was present when the blots were incubated with normal mouse serum or $\mathrm{IgG}_{1}$ isotype-matched control antibody in place of the anti-CD44 antibody (data not shown).

In addition, one predominant protein with a molecular mass of $\sim 85$ was immunoprecipitated from lung injury fibroblasts with the Hermes 1 and 3, and BU52 anti-CD44 monoclonal antibodies (Fig. $3 B$, lanes $A$ and $B$; data shown for Hermes 3 anti-

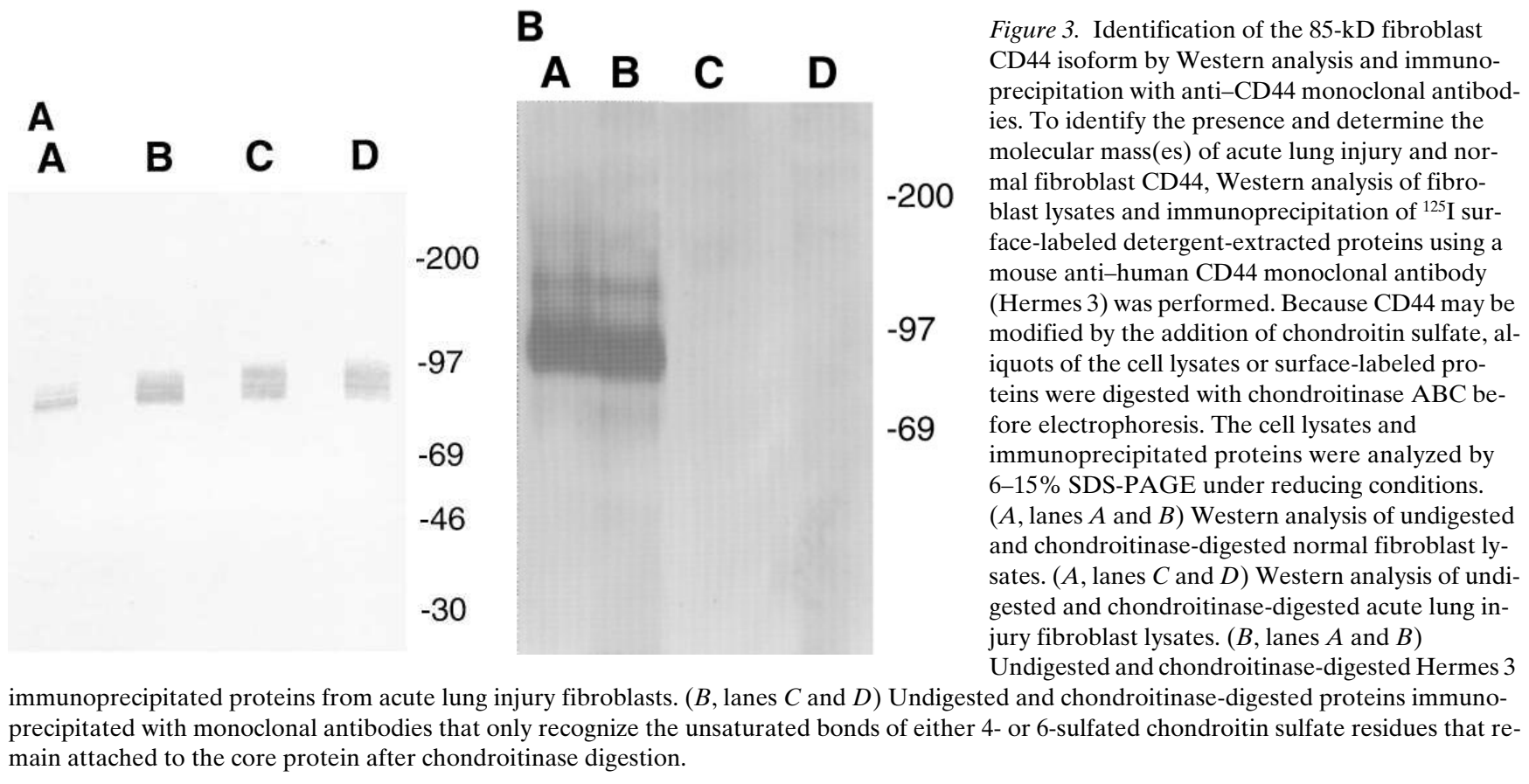


body only). This corresponds exactly to the large broad region of immunoreactivity apparent in the Western analysis. Similar to the Western analysis, there was no difference between chondroitinase-digested and -undigested samples, indicating that the $85-\mathrm{kD}$ protein isolated from fibroblasts is not significantly modified by chondroitin sulfate. Several faint bands were visible in both the undigested and digested lanes of immmunoprecipitated proteins at $<85,110$, and $150 \mathrm{kD}$ that have not been identified further. In light of the PCR and Western analysis data, it is unlikely that these bands represent additional CD44 isoforms and may represent nonspecific binding. As a control, rabbit anti-mouse IgG antibody coupled to protein A agarose beads failed to bind the proteoglycan core proteins (data not shown).

To further examine the issue of whether the CD44 protein was modified by the addition of chondroitin sulfate sidechains, ${ }^{125}$ I surface labeled detergent extracted proteins derived from acute lung-injury fibroblasts were immunoprecipitated using two mouse monoclonal antibodies that recognize the unsaturated bonds of 4-O and 6-O sulfated chondroitin sulfate residues that remain attached to proteoglycan core proteins after chondroitinase $\mathrm{ABC}$ digestion. No immunoprecipitated protein was present in the chondroitinase-digested lane at $85 \mathrm{kD}$ (Fig. $3 \mathrm{~B}$, lane $D$ ), indicating that the $85-\mathrm{kD}$ CD44 protein is not significantly modified by chondroitin sulfate. In addition, as expected, no bands were present in the undigested lane (Fig. $3 B$, lane $C$ ).

Location of acute lung injury fibroblast cell surface CD44. To determine the location of CD44 on the surface of migrating fibroblasts, the cells were labeled with an antibody to CD44. The fibroblasts were then examined by either indirect immunofluorescence microscopy (fluorescein-conjugated secondary antibody) or indirect whole-cell mount electron microscopy (gold-conjugated secondary antibody).

The epitope recognized by the anti-CD44 antibody (BU52) displayed an extensive, homogenous distribution over the cell surface when viewed by fluorescent microscopy. Bright blue-green labeling was seen on peripheral edges, including lamellipodia and filopodia, as well as lighter labeling of the dorsal surface. Some migrating cells were observed to possess densely labeled patches on the leading ruffled edges (Fig. 4A). Many cells displayed fine, punctate labeling of their dorsal areas, often coalescing to brightly labeling extrusions. Control cells unlabeled with the primary antibody demonstrated a faded orange-brown appearance (data not shown). Cells incubated with normal mouse serum or $\mathrm{IgG}_{1}$ isotype-matched control antibody were also essentially unlabeled (data not shown).

When examined by whole-cell mount transmission electron microscopy, this diffuse homogeneous appearance was also observed (Fig. $4 \mathrm{~B}$ ). Of particular relevance to cell migration, filopodia and lamellipodia, which are highly motile structures found at the leading edge of migrating fibroblasts and which participate in cell locomotion, were also labeled (Fig. 4, $C$ and $D)$. Control experiments were performed in which the antiCD44 antibody was replaced with either normal mouse serum or an $\mathrm{IgG}_{1}$ isotype-matched control antibody. Essentially, no labeling of control specimens was observed (Fig. 4, $E$ and $F$ ). These data indicate that the CD44 cell surface matrix receptor is present in a homogeneous pattern over the surface of the cell and can be found at the leading edge of motile cells and on filopodia and lamellipodia, structures involved in cell motility.

Cell surface CD44 mediates acute lung injury fibroblast invasion of a fibrin matrix. Having identified the presence and location of CD44 on migrating fibroblasts, we next sought to examine the importance of cell surface CD44 in mediating acute lung injury fibroblast invasion of fibrin by employing three-dimensional fibrin gels, using the technique described by Brown et al. (17). Acute lung injury fibroblasts plated in microliter dots beneath a layer of polymerized fibrin rapidly extended long, thin cytoplasmic processes into the fibrin gel, and then invaded the overlying gel out of the plane of focus of the bottom of the plate (Fig. 5). $1 \mathrm{~d}$ after plating, a few cells in each microdot had invaded the gel. By day 5, large numbers of cells had invaded the fibrin gel matrix (Fig. 6).

To evaluate a potential role of cell surface CD44 in mediating fibroblast invasion of a fibrin matrix, acute lung injury fibroblast invasion was observed in the presence of varying concentrations of anti-CD44 monoclonal antibody. Fibroblasts cultured in the presence of anti-CD44 monoclonal antibody exhibited a dose-dependent reduction in invasion of the fibrin gel (Fig. 6). At anti-CD44 antibody concentrations of 10 and $20 \mu \mathrm{g} / \mathrm{ml}$, fibroblast invasion into the fibrin matrices was completely inhibited (Fig. 6). Interestingly, at low concentrations of anti-CD44 antibody $(0.01 \mu \mathrm{g} / \mathrm{ml})$, fibroblast invasion at days 3 and 4 of the assay was slightly elevated above controls. However, at termination of the invasion assay on day 5, no significant difference in fibroblast invasion into fibrin was apparent when cells were cultured in the presence of low concentrations of anti-CD44 antibody compared with control. No inhibition of fibroblast invasion into the fibrin gels was observed in the presence of the mouse $\mathrm{IgG}_{1}$ isotype-matched control monoclonal antibody (Fig. 6), normal mouse $\mathrm{IgG}$, or anti- $\alpha_{2}$ integrin antibody (data not shown). Additionally, similar to acute lung injury fibroblasts, normal lung fibroblasts were able to invade fibrin gels. Invasion of these gels was inhibited in a concentration-dependent fashion by anti-CD44 antibody (data not shown). These studies indicate that cell surface CD44 is necessary for both acute lung injury and normal fibroblast invasion of three-dimensional fibrin matrices.

The Western analysis and immunoprecipitation data indicated that the $85-\mathrm{kD}$ acute lung injury CD44 protein was not significantly modified by chondroitin sulfate. We further examined whether small amounts of chondroitin sulfate on CD44 might mediate fibroblast invasion. To evaluate the potential role of chondroitin sulfate in mediating fibroblast invasion of fibrin, cell invasion was observed in the presence of $1 \mathrm{mM}$ $\beta$-D xyloside. The number of cells invading the gel at day 5 in the presence or absence of $\beta-D$ xyloside was not statistically significant ( $27 \pm 4$ vs $30 \pm 4$, respectively). This data is consistent with the interpretation that chondroitin sulfate, which may modify CD44, does not play a significant role in fibroblast invasion of fibrin.

To examine whether small amounts of hyaluronic acid possibly contaminating the fibrin gels might be playing a role in mediating fibroblast invasion, the fibrin gels were treated with hyaluronidase. Fibroblasts were capable of invading hyaluronidase-treated fibrin gels as effectively as untreated fibrin gels (data not shown).

Anti-CD44 antibody blocks acute lung injury fibroblast migration on fibronectin, fibrinogen, and hyaluronic acid. To further examine the role of CD44 in mediating acute lung injury fibroblast invasion of a fibrin matrix, the effects of mouse antihuman CD44 monoclonal antibodies on fibroblast motility were examined in Boyden chamber-type migration assays. Acute lung injury fibroblasts preincubated with the anti-CD44 monoclonal antibody exhibited a dose-dependent reduction in 

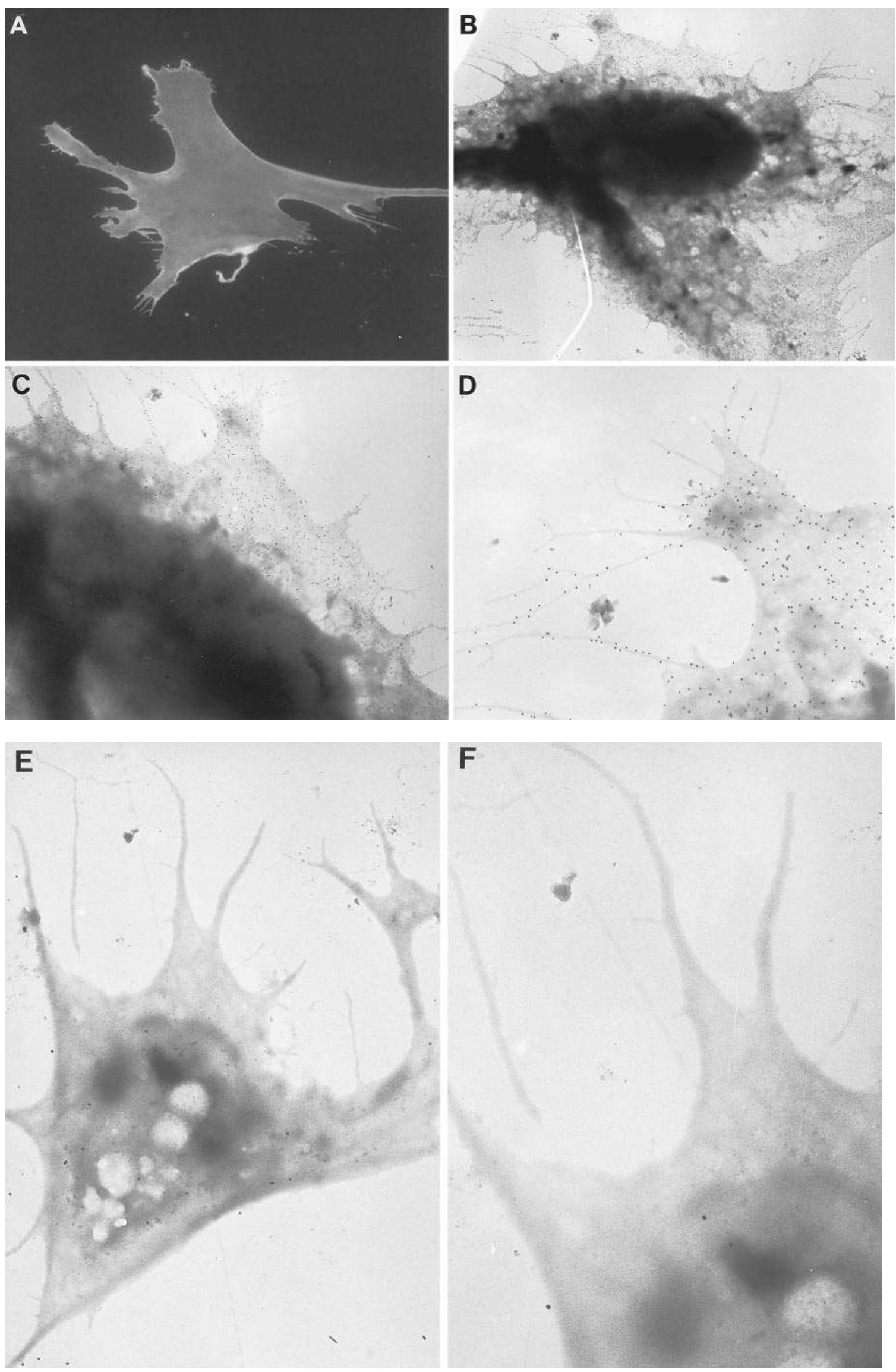


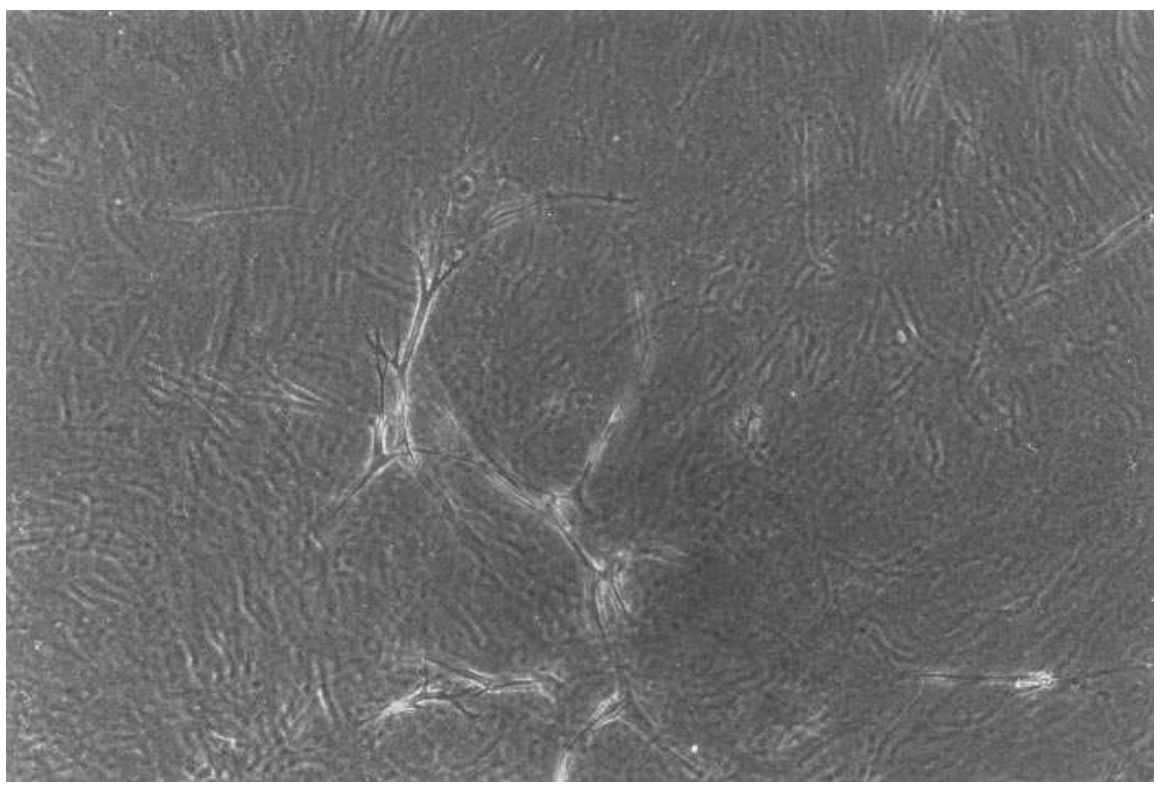

Figure 5. Acute lung injury fibroblast invasion of a fibrin matrix. Microdroplets of acute lung injury fibroblasts were allowed to attach to tissue culture dishes, and then were overlaid with a fibrin gel as described in Methods. Shown are fibroblasts invading the fibrin matrix. Cells attached to the bottom of the well are out of the plane of focus $(100 \times)$. migration on fibronectin $(10 \mu \mathrm{g} / \mathrm{ml})$ (Fig. $7 A)$. At $20 \mu \mathrm{g} / \mathrm{ml}$, anti-CD44 monoclonal antibody eliminated fibroblast migration on fibronectin. No reduction in acute lung injury fibroblast migration occurred when the cells were preincubated with a normal mouse $\mathrm{IgG}$ control antibody, mouse $\mathrm{IgG}_{1}$ isotype-matched control monoclonal antibody, or anti- $\alpha_{2}$ integrin antibody.

The role of CD44 in mediating fibroblast migration on fibrinogen $(0.5 \mu \mathrm{M})$ was also examined. Acute lung injury fibroblasts preincubated with anti-CD44 monoclonal antibody exhibited a dose-dependent reduction in migration on fibrinogen (Fig. $7 \mathrm{~B}$ ). Anti-CD44 monoclonal antibody at 10 and $20 \mu \mathrm{g} / \mathrm{ml} \mathrm{com-}$ pletely inhibited fibroblast migration on fibrinogen. No reduction in fibroblast migration on fibrinogen occurred when the cells were preincubated with control antibodies. In addition, pretreatment of fibronectin or fibrinogen solutions with hyaluronidase had no effect on fibroblast migration (data not shown).

Since hyaluronic acid accumulates in the wound provisional matrix (12-15) and has been associated with cell motility $(8,19)$, and since CD44 has been reported as a matrix adhesion receptor for hyaluronic acid (10), fibroblast migration on hyaluronic acid was examined after preincubation with antiCD44 antibody. Fibroblast migration on hyaluronic acid (5 $\mathrm{mg} / \mathrm{ml}$ ) was inhibited in a dose-dependent manner by antiCD44 antibody (Fig. 7 C). At an antibody concentration of 20 $\mu \mathrm{g} / \mathrm{ml}$, fibroblast migration on hyaluronic acid was completely inhibited. Control antibodies did not inhibit fibroblast migration on hyaluronic acid.

Similar to acute lung injury fibroblasts, anti-CD44 antibody also inhibited normal lung fibroblast migration on fi- bronectin, fibrinogen, and hyaluronic acid in a concentrationdependent fashion (data not shown).

Using low concentrations $(0.01 \mu \mathrm{g} / \mathrm{ml})$ of anti-CD44 antibody in the invasion assay, fibroblast invasion of fibrin was slightly elevated on days 3 and 4 of the assay compared with control. However, upon termination of the invasion assay at day 5 , there was no significant difference in fibroblast invasion of fibrin when cultured in the presence of low concentrations of anti-CD44 antibody compared with control. Similarly, there was no significant difference in fibroblast migration on fibronectin, fibrinogen, or hyaluronic acid when the cells were cultured in the presence of low concentrations $(0.01$ or $0.1 \mu \mathrm{g} /$ $\mathrm{ml}$ ) of anti-CD44 antibody compared with control antibody.

To examine the potential role of chondroitin sulfate modification of CD44 on cell motility, the effects of $\beta$-D xyloside and chondroitinase $\mathrm{ABC}$ on fibroblast motility were evaluated. Fibroblast motility on fibronectin coated filters were not affected by $1 \mathrm{mM} \beta$-D xyloside $(70 \pm 6)$ compared to no treatment $(65 \pm 5)$. Similarly, migration on fibronectin was not altered significantly by 0.1 or $0.5 \mathrm{U} / \mathrm{ml}$ of chondroitinase $\mathrm{ABC}$ (53 \pm 5 and $48 \pm 4$, respectively) compared to control (46 \pm 6$)$.

CD44 mediates fibroblast adhesion to fibronectin, fibrinogen, fibrin, and hyaluronic acid, but not to laminin. To determine whether cell surface CD44 plays a role in fibroblast adhesion to various wound provisional matrix molecules, thereby facilitating motility and invasion, fibroblasts were preincubated with anti-CD44 monoclonal antibody in varying concentrations.

Fibroblasts preincubated with the anti-CD44 monoclonal antibody exhibited a dose-dependent reduction in adhesion on

Figure 4. Localization of acute lung injury fibroblast cell surface CD44. To determine the location of CD44 on motile fibroblasts, the cells were incubated with anti-CD44 monoclonal antibody and examined by either indirect immunofluorescence microscopy using a fluorescein-conjugated secondary antibody, or by indirect whole-cell mount electron microscopy using a gold-conjugated secondary antibody. Using indirect immunofluorescence microscopy, a homogeneous distribution of CD44 was noted over the fibroblast surface. Some migrating cells possessed intensely labeled leading edges $(A)$. By whole-cell mount electron microscopy, CD44 could be found densely labeling filopodia and lamellipodia, cell structures that make initial contact with the substratum at the leading edge of motile fibroblasts $(B-D)$. In contrast, whole-cell mount electron microscopy of migrating lung injury fibroblasts did not detect cell surface labeling when an IgG isotype-matched control antibody was substituted for the anti-CD44 antibody $(E$ and $F)$. 


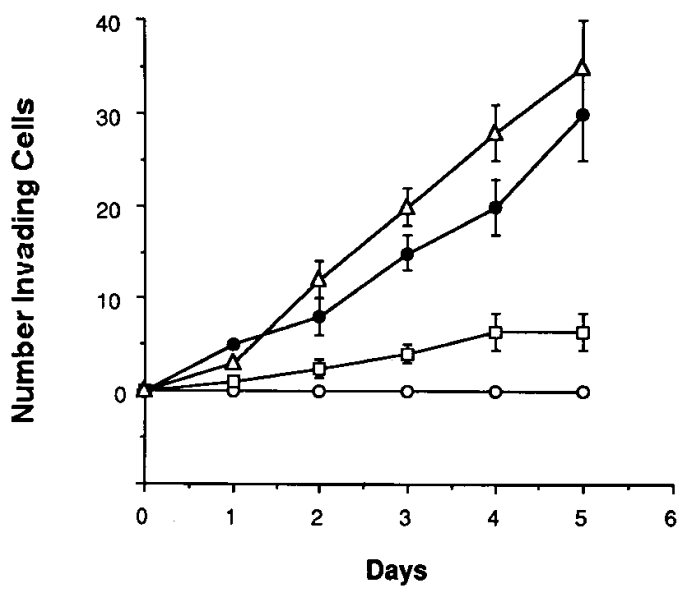

Figure 6. Anti-CD44 antibody inhibits acute lung injury fibroblast invasion of a fibrin matrix. Acute lung injury fibroblasts were allowed to attach and spread $\left(4 \mathrm{~h}, 37^{\circ} \mathrm{C}\right)$ on the surface of tissue culture wells. They were then overlayed with a fibrin gel and cultured in the presence of anti-CD44 monoclonal antibody in varying concentrations: $0.01 \mu \mathrm{g} / \mathrm{ml}(\triangle), 1.0 \mu \mathrm{g} / \mathrm{ml}(\square), 20 \mu \mathrm{g} / \mathrm{ml}(\bigcirc)$, or an isotype $\mathrm{IgG}_{1}$ control monoclonal antibody $(\bullet)$. Each time point represents the mean number of cells invading the gel/microdroplet \pm SEM of at least six microdroplets.

fibronectin $(10 \mu \mathrm{g} / \mathrm{ml})$ (Fig. $8 A$ ). At $20 \mu \mathrm{g} / \mathrm{ml}$, adhesion to fibronectin was decreased by $70 \%$. Cell appearance by phase contrast microscopy indicated that the cells remained rounded up and unable to spread in the presence of antibody (Fig. 9A). No reduction in fibroblast adhesion occurred when the cells were preincubated with control monoclonal antibodies (Fig. 8 $A$ ) and the cells were capable of spreading on fibronectin in the presence of control antibodies (data shown for mouse $\mathrm{IgG}_{1}$ antibody) (Fig. $9 \mathrm{~B}$ ).

Similarily, anti-CD44 monoclonal antibody blocked fibroblast adhesion to fibrinogen in a dose-dependent fashion (Fig. $8 \mathrm{~B}$ ). At the maximal concentration of antibody tested, $20 \mu \mathrm{g} /$ $\mathrm{ml}$, fibroblast adhesion to fibrinogen $(0.5 \mu \mathrm{M})$ was reduced by $\sim 50 \%$. Control antibodies had no effect on fibroblast adhesion to fibrinogen. Consistent with the invasion and migration assay results, pretreament of fibronectin and fibrinogen solutions with hyaluronidase did not effect fibroblast adhesion (data not shown).

Fibroblast adhesion to fibrin was examined by layering fibroblasts onto a fibrin gel. Fibroblast adhesion to the fibrin surface was blocked by the anti-CD44 monoclonal antibody in a dose-dependent fashion (Fig. 8 C). At $20 \mu \mathrm{g} / \mathrm{ml}$ antibody, fibroblast adhesion to fibrin was reduced by $47 \%$. The appearance of fibroblasts adhering to the fibrin gel indicated that some cells could still attach to the surface of the fibrin gel, but could not spread normally in the presence of anti-CD44 antibody (Fig. $9 \mathrm{C}$ ). Control monoclonal antibodies had no effect on fibroblast adhesion to fibrin (Fig. $8 C$ ) and the cells were capable of spreading on the surface of the fibrin gel in the presence of control antibodies (data shown for mouse $\mathrm{IgG}_{1}$ antibody) (Fig. $9 D$ ).

The $85-\mathrm{kD}$ isoform of CD44, also termed CD44H, is an adhesion receptor for hyaluronic acid (10). To determine whether acute lung injury fibroblasts use CD44 to adhere to hyaluronic acid, the cells were preincubated with the antiCD44 monoclonal antibody. Fibroblast adhesion to hyaluronic
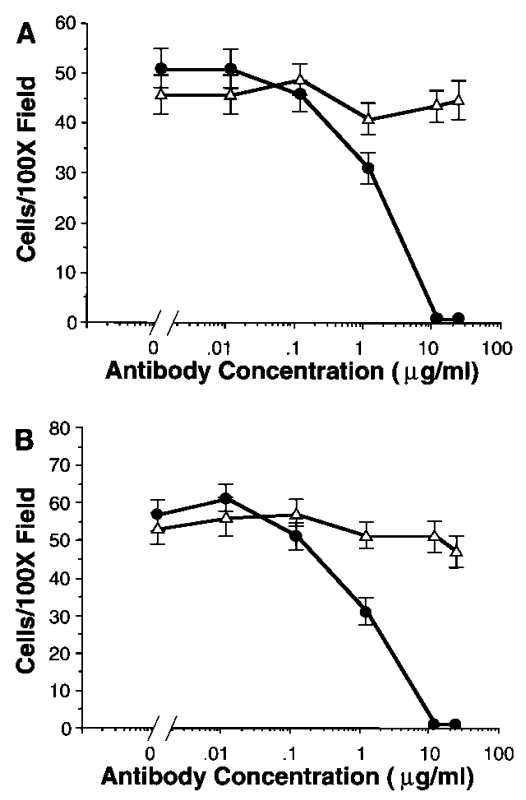

Figure 7. Fibroblast migration on the provisional matrix proteins fibronectin, fibrinogen, and hyaluronic acid are blocked by anti-CD44 antibody. Acute lung injury fibroblasts were preincubated for 30 min with varying concentrations of antiCD44 antibody. Fibroblast migration to the undersides of filters coated with fibronectin $(A)$, fibrinogen $(B)$, or hyaluronic acid $(C)$ were assessed using modified Boyden chambers in the presence of anti-CD44 antibody (•) or $\mathrm{IgG}_{1}$ isotypematched control antibody $(\triangle)$. Shown are the numbers of cells migrating per $100 \times$ field.

acid $(5 \mathrm{mg} / \mathrm{ml})$ was inhibited in a dose-dependent manner by anti-CD44 antibody (Fig. 8 D). Anti-CD44 monoclonal antibody, at a concentration of $20 \mu \mathrm{g} / \mathrm{ml}$, inhibited fibroblast adhesion to hyaluronic acid by $70 \%$. Control antibodies did not inhibit fibroblast attachment to hyaluronic acid.

In contrast, anti-CD44 monoclonal antibody did not block fibroblast adhesion to laminin (Fig. $8 \mathrm{E}$ ). At $20 \mu \mathrm{g} / \mathrm{ml}$ antibody, no reduction in cell adhesion occurred. Importantly, by phase contrast microscopy, the cells were capable of attaching and spreading on laminin in the presence of anti-CD44 antibody (Fig. $9 E$ ). Cells treated with control antibodies attached and spread normally (Figs. $8 E$ and $9 F$ ). This indicates that the effect of anti-CD44 monoclonal antibody in blocking fibroblast adhesion to fibronectin, fibrinogen, and fibrin was not due to a toxic effect on the cells. Similar results for the adhesion assay were obtained using normal lung fibroblasts. These data are consistent with the interpretation that CD44 is a fibroblast adhesion receptor for the provisional matrix proteins fibronectin, fibrinogen, fibrin, and hyaluronic acid, but not laminin, a component of the basement membrane.

Similar to the invasion and migration assay results, treatment of fibroblasts with $\beta$-D xyloside and chondroitinase ABC did not affect fibroblast adhesion. Fibroblast adhesion to fibronectin in the presence or absence of $1 \mathrm{mM} \beta$-D xyloside was $64 \pm 9$ and $65 \pm 13$, respectively. Additionally, fibroblast adherence to fibronectin was not significantly decreased in the presence of 0.1 or $0.5 \mathrm{U} / \mathrm{ml}$ chondroitinase $\mathrm{ABC}(62 \pm 11$ and $58 \pm 8$, 

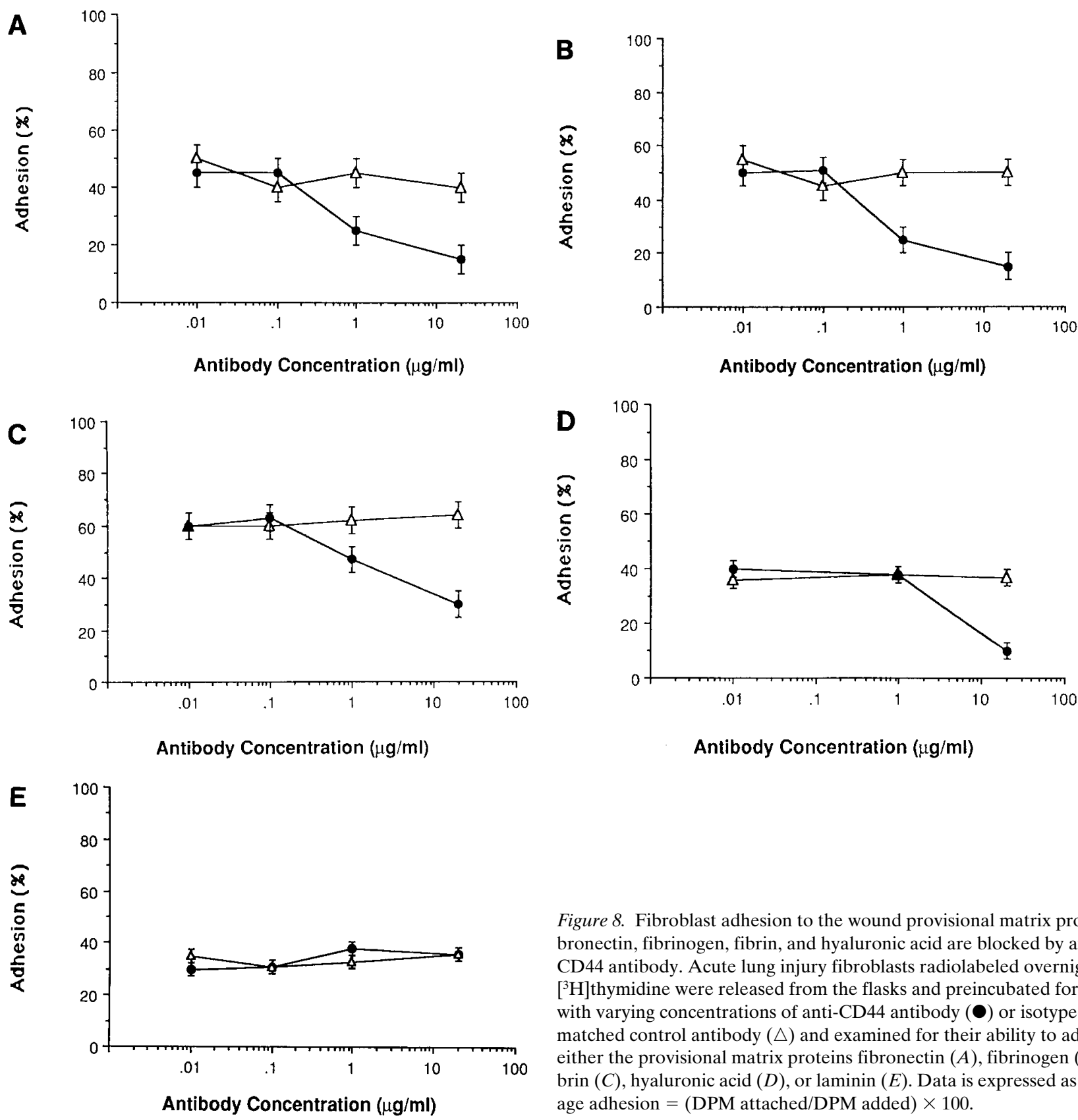

Figure 8. Fibroblast adhesion to the wound provisional matrix proteins fibronectin, fibrinogen, fibrin, and hyaluronic acid are blocked by antiCD44 antibody. Acute lung injury fibroblasts radiolabeled overnight with $\left[{ }^{3} \mathrm{H}\right]$ thymidine were released from the flasks and preincubated for $30 \mathrm{~min}$ with varying concentrations of anti-CD44 antibody $(\bullet)$ or isotypematched control antibody $(\triangle)$ and examined for their ability to adhere on either the provisional matrix proteins fibronectin $(A)$, fibrinogen $(B)$, fibrin $(C)$, hyaluronic acid $(D)$, or laminin $(E)$. Data is expressed as percentage adhesion $=($ DPM attached $/$ DPM added $) \times 100$.

respectively). Collectively, the Western and immunoprecipitation data together with the functional assay results indicate that chondroitin sulfate, which may modify CD44, does not have a substantial role in fibroblast adhesion, migration, or invasion.

\section{Discussion}

Fibrosis results when myofibroblasts invade the wound fibrin provisional matrix. Matrix receptors on the cell surface mediate cell adhesion, migration, and invasion of the extracellular matrix. The present study provides evidence that CD44, a matrix receptor on the surface of the fibroblast, plays a role in mediating the fibrotic response after lung injury. Importantly, using immunohistochemical techniques, CD44-express- ing mesenchymal cells were seen throughout newly formed fibrotic tissue in the injured lung. We have determined that acute lung injury fibroblasts express the $85-\mathrm{kD}$ isoform of CD44 on their cell surface. Using indirect immunofluorescence microscopy, CD44 was found to be distributed over the cell surface and could be detected concentrated along the leading edge of some motile fibroblasts. Whole-cell mount transmission electron microscopy also detected CD44 uniformly labeling the cell surface and importantly, was found labeling filopodia and lamellipodia, that are highly motile structures at the leading edge of migrating cells that participate in cell motility. The importance of CD44 in mediating fibroblast migration and invasion into fibrin was demonstrated by inhibiting the function of CD44 with monoclonal antibodies. Fibroblast migration on provisional matrix proteins and invasion of a fi- 
brin matrix was completely inhibited by treatment with antiCD44 monoclonal antibodies. We have determined that disruption of fibroblast cell surface CD44 function by anti-CD44 antibody inhibits adhesion to various components of the wound provisional matrix including fibrin, fibrinogen, and fibronectin, but not for laminin, a component of basement membranes. Collectively, these data are consistent with the hypothesis that CD44 functions as a matrix adhesion receptor on the surface of fibroblasts, thereby mediating motility and invasion of the wound provisional matrix resulting in the formation of fibrotic tissue.

Multiple isoforms of CD44 exist as a result of alternative splicing of a series of exons. The diversity of CD44 can be further amplified by the differential use of glycosaminoglycan attachment sites on its extracellular domain. For example, various isoforms of CD44 may be modified by the addition of
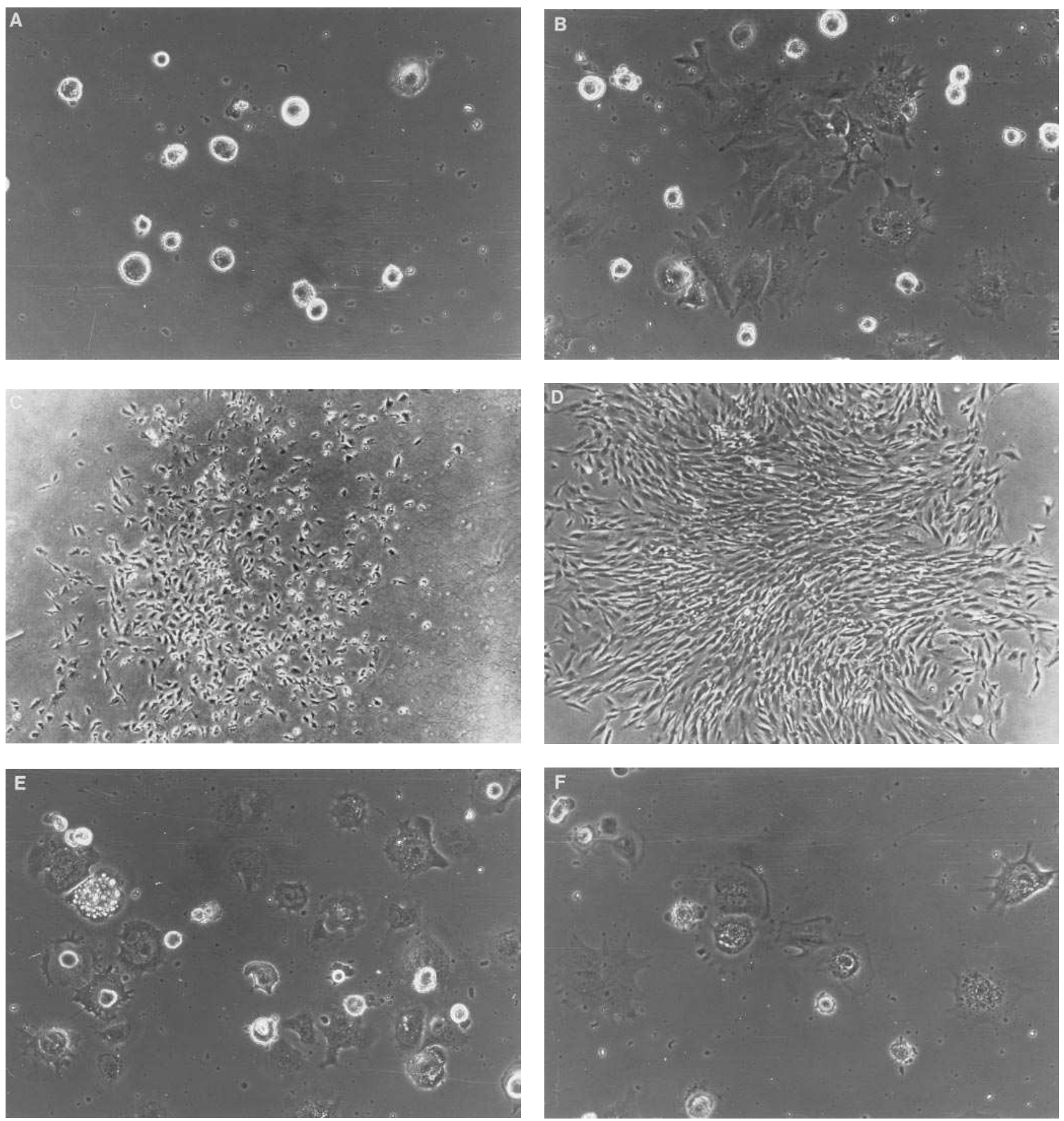

Figure 9. Phase contrast microscopic appearance of adhesion assay. Shown are the phase contrast appearance of fibroblasts cultured in the presence of either anti-CD44 antibody $(A, C, E)$ or $\operatorname{IgG}_{1}$ isotype-matched control antibody $(B, D, F)$ and adhering to fibronectin $(A$ and $B)$, fibrin $(C$ and $D)$, or laminin $(E$ and $F)(200 \times)$. Note round appearance of cells adhering to fibronectin and fibrin in the presence of anti-CD44 antibody. Also note spread appearance of fibroblasts adhering to laminin in the presence of anti-CD44 antibody. 
chondroitin sulfate. The chondroitin sulfate on CD44 appears to play important roles in mediating the migration of several cell types $(5,27)$. Our data indicate that fibroblasts express one CD44 isoform, the $85-\mathrm{kD}$, or standard isoform, which by Western and immunoprecipitation analysis does not appear to be modified by chondroitin sulfate.

Importantly, various isoforms of CD44 have been associated with enhanced migration and invasion of transformed cells. For example, the $85-\mathrm{kD}$ isoform of CD44, also termed $\mathrm{CD} 44 \mathrm{H}$, promotes melanoma cell migration on hyaluronatecoated surfaces $(8,28)$. In addition, a $110-\mathrm{kD}$ isoform of CD44, modified by the addition of chondroitin sulfate in mouse melanoma cells, mediates their invasion of collagen matrices (5). Furthermore, transfection of the cDNA of a large molecular weight (150-200 kD) variant isoform of CD44, characterized by the presence of variant exon 6 , conferred metastatic behavior to a nonmetastatic rat pancreatic tumor line $(6,7)$. In the present study, the $85-\mathrm{kD}$ isoform of CD44 is the predominant isoform on the surface of acute lung injury and normal fibroblasts. The $85-\mathrm{kD}$ isoform of CD44 has been reported to be a matrix adhesion receptor for hyaluronic acid. Our adhesion and migration assay data are consistent with this finding and indicate that the $85-\mathrm{kD}$ isoform of CD44 found on acute lung injury fibroblasts also mediates their adhesion and migration on hyaluronic acid.

CD44 has also been shown to be a matrix receptor for fibronectin and type I collagen $(29,30)$. Our adhesion assay data suggest that fibroblast CD44 functions as an adhesion receptor for a variety of wound provisional matrix proteins including fibrin/fibrinogen, in addition to fibronectin, and hyaluronic acid. However, whether fibroblast CD44 mediates adhesion or migration to fibrin(ogen) by directly interacting with fibrin(ogen) or by an indirect mechanism remains uncertain. Regarding an indirect mechanism, it has been proposed that hyaluronic acid bound to fibrin may provide the stimulus for cell migration during the wound healing process (31). In this model, a concentration gradient of hyaluronic acid bound to fibrin in solid phase supports the directed migration of fibroblasts (haptotaxis). To begin to address the issue of whether CD44 directly or indirectly interacts with fibrin(ogen), we have performed adhesion, migration, and invasion assays using HPLC-DEAE purified fibrinogen and fibrinogen pretreated with hyaluronidase. Fibroblasts were capable of attaching and migrating on fibrinogen-coated surfaces and invading fibrin matrices using both HPLC-purified and hyaluronidase-treated fibrinogen. These data suggest that fibroblast CD44 may be able to directly interact with fibrin, thereby mediating cell adhesion and migration. However, reagents other than fibrinogen used in these assays may be contaminated with hyaluronic acid. Therefore the issue of whether CD44 interacts directly or indirectly with fibrin(ogen) remains to be defined. Interestingly, CD44 does not appear to promote fibroblast attachment to laminin, a component of the basement membrane. Furthermore, our ultrastructural analysis data is consistent with a role for CD44 as a surface matrix adhesion receptor involved with cell locomotion. CD44 was found to be distributed uniformly over the surface of the cell. Important however, was the finding that CD44 could be found concentrated along the leading ruffled edge of some migrating fibroblasts and was present on filopodia and lamellipodia, which are highly motile structures on the leading edge of migrating cells that are involved in cell movement. Therefore, since fibroblast CD44 can be found on cellular structures that participate in cell migration, this suggests a role for this adhesion receptor in fibroblast migration.

Previous work has implicated fibroblast cell surface CD44 with the development of fibrosis, but direct evidence identifying CD44 with fibroblast motility and invasion of the wound fibrin provisional matrix has been lacking. In the first study to link fibroblast CD44 with the fibrotic response, Messadi and Bertolami (20) found increased expression of CD44 in hypertrophic scar fibroblasts compared to normal skin fibroblasts. The current study provides direct evidence that fibroblast cell surface CD44 mediates fibroblast migration and invasion of a fibrin matrix. Employing the fibrin gel invasion assay, blockage of CD44 function with monoclonal antibodies eliminated the ability of fibroblasts to invade the fibrin matrix. Furthermore, prior studies have determined that after the onset of tissue injury, a meshwork of fibrin, rich in fibronectin and hyaluronan, accumulates in the wound extracellular space $(1,12-15)$. Over several days, this provisional matrix becomes organized by invading fibroblasts. This temporal sequence of fibronectin and hyaluronic acid accumulation in the provisional matrix followed by fibroblast invasion is important in light of the results of our adhesion and migration assays. Blockage of CD44 function with monoclonal antibodies effectively inhibited fibroblast adhesion and migration on the provisional matrix proteins, hyaluronan, and fibronectin. These results suggest that CD44 interaction with fibronectin and hyaluronan are important in fibroblast motility. Importantly, our immunohistochemical analysis further links fibroblast cell surface CD44 with the development of fibrosis. We have identified CD44-expressing fibroblasts in newly formed fibrotic tissue in the acutely injured lung. Taken together, these data provide strong support for the role of CD44 in mediating fibroblast migration and invasion of the fibrin provisional matrix and the subsequent development of tissue fibrosis.

Our data indicate that both acute lung injury and normal fibroblasts express the $85-\mathrm{kD}$ isoform of CD44. In addition, both lung injury and normal fibroblast invasion of fibrin matrices can be blocked by anti-CD44 antibody, indicating a role for CD44 in fibroblast invasion of the provisional matrix after organ/tissue injury. Since both normal and lung-injured fibroblasts use CD44 for adhesion and migration, as well as invasion of fibrin, this suggests that CD44 use may not be restricted to the fibrotic disease state, but may also be involved in normal fibroblast function. However, since "normal" lung fibroblasts in culture have been extensively manipulated, one cannot be certain that their phenotype is indeed characteristic of normal fibroblasts in vivo. Consistent with this concept, depending on culture conditions, normal fibroblasts in culture may display several morphologic and biochemical markers characteristic of wound fibroblasts such as stress fibers, gap junctions, high amounts of actin, and $\alpha$-smooth muscle actin (32).

Our immunohistochemical analysis performed on lunginjured tissue demonstrates sheets of CD44-positive mesenchymal cells comprising newly formed fibrotic lesions. This result can be interpreted several different ways. First, there exists the possibility that expansion of a small subpopulation of CD44-positive fibroblasts may play a crucial role in fibrogenesis. Alternatively, in the injured alveolar microenvironment, a change in the fibroblast phenotype from a quiescent, CD44-negative cell (or low level of expression) to an activated state may result in a population of CD44-positive cells. The data by Messadi and Bertolami (20), which demonstrate that 
CD44 expression is increased in hypertrophic scar fibroblasts compared with normal skin fibroblasts supports the latter hypothesis. Recent work indicates that lung fibroblasts undergo phenotypic modulation into myofibroblasts during bleomycininduced pulmonary fibrosis (33). Moreover, the presence of transforming growth factor $\beta$ and tumor necrosis factor $\alpha$ in the fibrotic lung microenvironment has been implicated in regulating the modulation of the fibroblast phenotype into a wound phenotype (34). These data, combined with our immunohistochemical analysis showing low to undetectable CD44 staining of fibroblasts in normal tissue suggest that modulation of fibroblast phenotype into CD44-expressing cells is associated with the development of fibrotic tissue. Clearly, further studies are needed to clarify the function and role of fibroblast CD44 in normal and disease states. However, our data does directly link CD44 with fibroblast migration and invasion in one particular disease state, acute lung injury.

Identifying receptors such as CD44 involved in mediating such cellular functions as fibroblast adhesion, migration, and invasion may be critical in ultimately understanding and controlling the fibrotic response. Recent studies have shown that synthetic fibronectin peptides are capable of inhibiting leukocyte adhesion to synovial tissue and suppress inflammation in a rat arthritis model (35). The key feature of this study was the finding that these peptides could interrupt leukocyte adhesion and recruitment in active, ongoing inflammatory disease. Analogously, this suggests that blocking adhesion receptor function on fibroblasts (e.g., the CD44 receptor) may provide a means of regulating the development of fibrosis in critical regions of injured organs such as the airspace after lung injury. The plausibility of this hypothesis is suggested by our invasion assays in which fibroblast invasion of the fibrin matrix could be inhibited by anti-CD44 antibody. Further investigations using animal models of fibrosis will be important in determining whether interruption of CD44 function may attenuate or arrest the fibrotic response.

\section{Acknowledgments}

The authors thank Peter Bitterman and Mark Peterson for their excellent technical advice and critical review of the manuscript.

This research has been supported by National Institutes of Health grant F32 HL-08051-02 (C. Henke), National Heart, Lung, and Blood Institute SCOR in Acute Lung Injury grant HL 50152-01 (Project 2, C. Henke) from the National Institutes of Health and the Minnesota Medical Foundation Medical Student Scholarship Program (K. Svee).

\section{References}

1. Brown, L.F., A.M. Dvorak, and H.F. Dvorak. 1989. Leaky vessels, fibrin deposition, and fibrosis: a sequence of events common to solid tumors and to many other types of disease. Am. Rev. Respir. Dis. 140:1104-1107.

2. Henke, C., V. Fiegel, M. Peterson, M. Wick, D. Knighton, J. McCarthy, and P. Bitterman. 1991. Identification and partial characterization of angiogenesis bioactivity in the lower respiratory tract after acute lung injury. J. Clin. Invest. 88:1386-1395.

3. Henke, C., W. Marinelli, J. Jessurun, J. Fox, D. Harms, M. Peterson, L. Chiang, and P. Doran. 1993. Macrophage production of basic fibroblast growth factor in the fibroproliferative disorder of alveolar fibrosis after lung injury. Am. J. Pathol. 143:1189-1199.

4. Turley, E.A., and J. Torrance. 1984. Localization of hyaluronate and hyaluronate-binding protein on motile and non-motile fibroblasts. Exp. Cell Res. 161:17-28.

5. Faassen, A.E., J.A. Schrager, D.J. Klein, T.R. Oegema, J.R. Couchman, and J.B. McCarthy. 1992. A cell surface chondroitin sulfate proteoglycan, immunologically related to CD44, is involved in type I collagen-mediated mela- noma cell motility and invasion. J. Cell Biol. 116:521-531.

6. Gunthert, U., M. Hofmann, W. Rudy, S. Reber, M. Zoller, I. Baußmann, S. Matzku, A. Wenzel, H. Ponta, and P. Herrlich. 1991. A new varient of glycoprotein CD44 confers metastatic potential to rat carcinoma cells. Cell. 65:13-24.

7. Rudy, W., M. Hofmann, R. Schwartz-Albiez, M. Zoller, K.H. Heider, H Ponta, and P. Herrlich. 1993. The two major CD44 proteins expressed on a metastatic rat tumor cell line are derived from different splice varients: each one individually suffices to confer metastatic behavior. Cancer Res. 53:12621268.

8. Thomas, L., R. Byers, J. Vink, and I. Stamenkovic. 1992. CD44H regulates tumor cell migration on hyaluronate-coated substrate. J. Cell Biol. 118: 971-977.

9. Sy, M.S., Y.J. Guo, and I. Stamenkovic. 1991. Distinct effects of two CD44 isoforms on tumor growth in vivo. J. Exp. Med. 174:859-866.

10. Aruffo, A., I. Stamenkovic, M. Melnick, C.B. Underhill, and B. Seed 1990. CD44 is the principal cell surface receptor for hyaluronate. Cell. 61:13031313.

11. Jalkanen, S., and M. Jalkanen. 1992. Lymphocyte CD44 binds the COOH-terminal heparin-binding domain of fibronectin. J. Cell Biol. 116:817825 .

12. Bray, B.A., P.M. Sampson, M. Osman, A. Giandomenico, and G.M Turino. 1991. Early changes in lung tissue hyaluronan (hyaluronic acid) and hyaluronidase in bleomycin-induced alveolitis in hamsters. Am. Rev. Respir. Dis. 143:284-288.

13. Hallgren, R., T. Samuelsson, T.C. Laurent, and J. Modig. 1989. Accumulation of hyaluronan (hyaluronic acid) in the lung in adult respiratory distress syndrome. Am. Rev. Respir. Dis. 139:682-687.

14. Laurent, T.C., and R.E. Fraser. 1992. Hyaluronan. FASEB (Fed. Am. Soc. Exp. Biol.) J. 6:2397-2404.

15. Weigel, P.H., S.J. Frost, R.D. LeBoeuf, and C.T. McGary. 1989. The specific interaction between fibrinogen and hyaluronan: possible consequences in haemostasis, inflammation, and wound healing. Ciba Found. Symp. 143:248264.

16. McCarthy, J.B., S.T. Hagen, and L.T. Furcht. 1986. Human fibronectin contains distinct adhesion- and motility-promoting domains for metastatic melanoma cells. J. Cell Biol. 103:179-188.

17. Brown, L.F., N. Lanir, J. McDonagh, K. Tognazzi, A.M. Dvorak, and H.F. Dvorak. 1993. Fibroblast migration in fibrin gel matrices. Am. J. Pathol. 142:273-283.

18. Clark, R.A.F., J.M. Lanigan, P. DellaPelle, E. Manseau, H.F. Dvorak, and R.B. Colvin. 1982. Fibronectin and fibrin provide a provisional matrix for epidermal cell migration during wound reepithelialization. J. Invest. Dermatol. 79:264-269.

19. Turley, E.A. 1992. Hyaluronan and cell locomotion. Cancer Metastasis. Rev. 11:21-30

20. Messadi, D.V., and C.N. Bertolami. 1993. CD44 and hyaluronan expression in human cutaneous scar fibroblasts. Am. J. Pathol. 142:1041-1049.

21. Chen, B., V. Polunovsky, J. White, B. Blazar, R. Nakhleh, J. Jessurun, M. Peterson, and P. Bitterman. 1992. Mesenchymal cells isolated after acute lung injury manifest an enhanced proliferative phenotype. J. Clin. Invest. 90: $1778-1785$.

22. Fowler, A.A., R.F. Hamman, G.O. Zerbe, K.N. Benson, and T.M. Hyers. 1985. Adult respiratory distress syndrome: prognosis after onset. Am. Rev. Respir. Dis. 132:472-478.

23. Petty, T.L., and D.G. Ashbaugh. 1971. The adult respiratory distress syndrome. Chest. 60:233-239.

24. Bennett, K.L., D.G. Jackson, J.C. Simon, E. Tanczos, R. Peach, B. Modrell, I. Stamenkovic, G. Plowman, and A. Aruffo. 1995. CD44 isoforms containing variant exon V3 are responsible for the presentation of heparinbinding growth factor. J. Cell Biol. 128:687-698.

25. van Weering, D.H.J., P.D. Baas, and J.L. Bos. 1993. A PCR-based method for the analysis of human CD44 splice variants. PCR Methods Applications. 3:100-106.

26. Iida, J., A.P.N. Skubitz, L.T. Furcht, E.A. Wayner, and J.B. McCarthy 1992. Coordinate role for the cell surface chondroitin sulfate proteoglycan and $\alpha_{4} \beta_{1}$ integrin in mediating melanoma cell adhesion to fibronectin. J. Cell Biol. 118:431-444.

27. Henke, C.A., U. Roongta, D.J. Mickelson, J.R. Knutson, and J.B. McCarthy. 1996. CD44-related chondroitin sulfate proteoglycan, a cell surface receptor implicated with tumor cell invasion, mediates endothelial cell migration on fibrinogen and invasion into a fibrin matrix. J. Clin. Invest. 97:2541-2552.

28. Stamenkovic, I., A. Aruffo, M. Amiot, and B. Seed. 1991. The hematopoietic and epithelial forms of CD44 are distinct polypeptides with different adhesion potentials for hyaluronate bearing cells. EMBO (Eur. Mol. Biol. Organ.) J. 10:343-348

29. Jalkanen, S., and M. Jalkanen. 1992. Lymphocyte CD44 binds the COOH-terminal heparin-binding domain of fibronectin. J. Cell Biol. 116:817825 .

30. Wayner, E.A., and W.G. Carter. 1987. Identification of multiple cell adhesion receptors for collagen and fibronectin in human fibrosarcoma cells possessing unique $\alpha$ and common $\beta$ subunits. J. Cell Biol. 105:1873-1884.

31. Weigel, P.H., G.M. Fuller, and R.D. LeBoeuf. 1986. A model for the 
role of hyaluronic acid and fibrin in the early events during the inflammatory response and wound healing. J. Theor. Biol. 119:219-234.

32. Darby, I., O. Skalli, and G. Gabbiani. 1990. $\alpha$-smooth muscle actin is transiently expressed by myofibroblasts during experimental wound healing. Lab. Invest. 63:21-29.

33. Vyalov, S.L., G. Gabbiani, and Y. Kapanci. 1993. Rat alveolar myofibroblasts acquire alpha-smooth muscle actin expression during bleomycin-induced pulmonary fibrosis. Am. J. Pathol. 143:1754-1765.

34. Kapanci, Y., A. Desmouliere, J.C. Pache, M. Redard, and G. Gabbiani.
1995. Cytoskeletal protein modulation in pulmonary alveolar myofibroblasts during idiopathic pulmonary fibrosis. Possible role of transforming growth factor beta and tumor necrosis factor alpha. Am. J. Respir. Crit. Care Med. 152: 2163-2169.

35. Wahl, S.M., J.B. Allen, K.L. Hines, T. Imamichi, A.M. Wahl, L.T. Furcht, and J.B. McCarthy. 1994. Synthetic fibronectin peptides suppress arthritis in rats by interrupting leukocyte adhesion and recruitment. J. Clin. Invest. 94:655-662. 